consider one of the two principal sources of the Amu-daria, the other being the Pianj. According to their statements the Aksu, which waters the Pamir, is an affluent of the Wanj, and doe not fall into the Pianj near Kala Wamar, the affluent of the Pianj being called the Chun'uk-daria, which flows out of the Yashil-kul. In order to assure himself of the truth of these statements Dr. Regel followed the Wanj as far as Tesh-i-Senghi, and he found that the river contained abundance of water. $\mathrm{He}$ intended to spend the winter at Darwaz, in order to resume his explorations in the spring, and it may be hoped that he will succeed in solving the last remaining mysteries of the Pamir.

Mr. S. E. Peal's account of his expedition in 1879 to the Nongyang Lake aud to the pass over the Patkoi Range will be found, with map and panoramic sketches, in Part 2, No. I, of the Bengal Asiatic Society's Fournal for I88r.

THE following despatch has been received at the London office of the New York Herald:- "Irkutsk, February I, 1882, 2.45 p.m. Our three boats left Semenofsky Island on the morning of September I2, bound for Barkin, ninety five miles distant. We got clear of ice at noon. Heavy gale from northeast, and boats dispersed during night; captain's boat, loaded deep, lost mast and sails. We made land on the evening of the $x 7$ th, shoal water. Boat abandoned two miles from beach; party waded and reached deserted village, Saga-tor; 'cachéd' $\log$ books ; proceeded south on the Igth. Delong's last record found reads as follows:--Saturday, October Ist.-Fourteen of the officers and men of the Feannette reached this hut on Wednesday, September 28 , and having been forced to wait for the river to freeze over, are proceeding to cross to the west side this morning on their journey to reach some settlement on the Lena River. 'We have only two days' provisions, but having been fortunate enough thus far to get game in our pressing needs we have no fears for the future. Our party all well, except Ericksen, whose toes have been amputated in consequence of frostbites. Other records will be found in several huts on the east side of the river, along which we have come from the north.-(Signed) GEORGE W. DELONG.' Three subsequent records had been found. Ericksen died October 7 ; party in great distress for food. Noros and Nindemann sent ahead for relief, October 9. They marched south fifteen days, and were found in a starving condition, October 24, by three natives, who took them to a settlement. They could not make themselves understood. News of them reached us October 29. Immediate search commenced, and party traced to a wilderness on left bank of Lena. Natives refused further work, and return to Bulong; was necessary to get Russian assistance. - November 28. - A large party is now searching, having to dig out everything deeply covered with snow. The wilderness devoid of game. Very prompt and efficient action by Russians. Every effort is being made. Jack Cole's tranquil to-day ; violent only at times ; softening of brain. My left eye ruined, and right one badly impaired. Other men well- Jackson has telegraphed me from Orenburg.--JoHN DANENHAUER." Semenofsky Island is probably a small island marked Semenov in the map in the "Voyage of the Vega," on the north-west of Stobovoi Island in the New Siberia group. Barkin is on the north-east point of the Lena delta, where there is a winter tent. Sagastyr, where they landed, is at the mouth of the most northern branch of the Lena delta. The engineer Melville has made arrangements for a thorough search for the missing party, at once.

\section{THE PRIZES OF THE PARIS ACADEMY OF SCIENCES}

THE annual distribution of prizes at the Academy of Sciences took place on Monday February 6. M. Wurtz, president for the year 188I, wes in the chair. The list of laureates was read by M. Dumas.

The prize of $240 l$. for any improvement in the French naval forces was awarded to $M$. Sébert for his apparatus for measuring the velocity of projectiles, and to $\mathbf{M}$. Brault for his study of naval meteorology.

The Lalande Prize was awarded to Prof. Swift of Rochester, (U.S.) for the discovery of seven comets in the brief interval of four years. Another astronomical prize was awarded to Mr. D. Gill, director of the Cape Observatory, for his determination of the solar parallax by observations of Mars.

The prize in Physics was awarded to M. Planté for his accumulators, and the Commission records the wonderful experiment which was executed by this physieist when he obtained a tension of 1200 element; with two Bunsens. Amongst the other prizes which may present some special interest are the following:-M. Briot, for his work, "Sur les Fonctions Abeliennes"; M. Etienne Gilbert, "Etude sur les Philtres, Charmes, Poisons." No prize was awarded for the question "to ascertain by direct observations and experiments the influence of exterior objects on the structure of vegetative organs," but a sum of $60 l$. was delivered to M. Mer to encourage him to work again at the same question which remains open for competition in 1882. One of the Monthyon Prizes was awarded to Dr. Favre for his work on Daltonism, and another to Dr. Paul Richer for a treatise on hystero-epilepsy. M. Collin took the interest of the Breant Prize for his work on "Epidemical Affections." This prize, originally destined for a remedy against cholera, amounts to $4000 l$, and the interest is distributed every year, to avoid indefinite accumulation. A posthumous prize was awarded to M. Henri St. Claire Deville for his discovery of the law of dissociation. The rules forbid the Academy to give such an honour to any of its living members, and it is the first time on record that it has been given to a departed one.

When the long series of laureates was recited, M. Bertrand, perpetual secretary for the section of Mathematical Sciences, read the eloge of Leon Foucault, the inventor of the gyroscope, electric light regulator, siderostat, silvered glass telescopes, determination of velocity of light, \&c. M. Leon Foucault was born in Paris in 1819 , he died in the same city in 1868 , and never travelled abroad. He was self-educated, having passed his honours only when already illustrious. M. Bertrand has written the preface to the collection of his scientific works, published in 1878 by his mother-a large 4 to volume of 600 pages. M. Leon Foucault was besides a very active and successful writer, having been the scientific editor of the Feuilleton of the Debats for years. His succes: or is now M. de Parville.

\section{INSTITUTION OF MECHANICAL ENGINEERS}

THE Annual General Meeting of this Institution was held at the Institution of Civil Engineers, Great George Street, on January 26 and 27 .

The Annual Report of the Council drew attention to the subjects of experimental research, of which some account has already been given in NATURE. With regard to riveted joints, it appears that a long and elaborate series of experiments have been carried on for the Committee by Prof. Kennedy, at the Engineering Laboratory, University College. These experiments dealt excluvively with steel plates and rivets, and were directed first to ascertain the constants of resistance to tension, shearing, \&c., in mild steel, the knowledge of which is necessary in order to design the strongest form of joint, and secondly to test joints designed on the basis of the values thus discovered, as against other joints, made purposely to have an excess or defect in one or other of the areas through which fracture might take place. The work has heen completely successful ; the correctly-designed joints giving decidedly the best results, and thus affording a satisfactory verification of the value determined for the constants. The experiments have further brought out strongly the fact that joints in iron and steel must be designed in a very different manner to give the best results in each, the reason being that the shearing resistance of the rivets is about the same in iron and steel, while the tensile resistance is much higher in the latter than the former. Hence the deduction that manufacturers, who have been content simply to transfer to steel the rules they have been in the habit of using for iron, have thereby involved themselves in serious error.

With regard to the other subject, the hardening and tempering of steel, the Institution have just published some very interesting researches made for them by Prof, Abel, C.B., F.R.S., and also by Prof. Chandler Roberts, F.R.S. The former has shown, by the analysis of thin disks of hardened and unhardened steel, the high probability that in unhardened steel the carbon is present as a definite carbide of iron (probable composition $\mathrm{Fe}_{6} \mathrm{C}_{5}$ ), eliminated from the iron in a more or less crystalline form; that on heating, this compound is dissolved in, or assimilated by, the metal; and that sudden cooling does not allow time for the elimination to take place, the carbide thus remaining dissolved, more or less completely, and giving a corresponding degree of hardness to the mass. Prof. Chandler Roberts' researches bear on a suggestion which had been made, that the hardening of steel was connected with the ccclusion and exclusion of gases by 